neighbourhood of the boundary in some sort of manner as shown in Fig. 2.

This would account qualitatively for the facts. A mathematical development on these lines would be necessary in order to show whether it also gave quantitative agreement.

Radio Research Board Station, Slough.

\section{Spermatogenesis of Spiders.}

I HAVE been much interested in Prof. Ernest Warren's letter in NATURE of September I 2 on the spermatogenesis of spiders, in which he claims amitotic division of spermatogonia, an abnormal type of maturation, and finally the formation of many spermatozoa from chromatin bodies, bereft of cytoplasm.

I recognise that it is naturally difficult for any one, in the limited space afforded by a letter to NATURE, to give an adequate account of the phenomena described by Prof. Warren; nevertheless, I feel that there is need for caution in accepting his results. The spermatogonial nucleus is polymorphic and lobulated, in itself no evidence of amitosis : the great Meves himself mistook the polymorphism of amphibian germ cells for amitosis - a mistake finally cleared up by Champy.

The formation of more than four spermatids from one spermatocyte is known in moths, where this effect is brought about by an extra, but normal, mitotic division.

Prof. Warren's figures 9-I2 seem to recall apyrene sperm formation, or the degenerative changes found in many effete insect germ cells.

I feel that while Prof. Warren has described what may be an interesting cytologic phenomenon, he has not convinced your readers that fertilisation in his spider is not brought about by a normally formed sperm.

Nevertheless, I would be glad to see some of Prof. Ernest Warren's material upon which his results are based.

Trinity College, Dublin, September Is

PROF. WARREN's most interesting letter in NATURE of September I 2 on the subject of spiders concludes with the challenging remark that "It would be obviously absurd to suppose that the mechanism of heredity differs fundamentally in certain spiders from that in other organisms. . . " Why absurd ? Spiders belong to a line of evolution remote from the mammals, for example, and a line which obviously "stuck"; and may this not be because its mechanism of heredity was not entirely satisfactory? Other lines carried on to the higher groups, and may it not be just because mammals possess a somewhat different and more useful mechanism for their heredity ?

Marie C. STopes.

Givons Grove, Leatherhead, Surrey.

\section{Antimonial Analogues of the Cacodyl Series.}

In view of the interest now manifested in organic derivatives of antimony, we desire to place on record our discovery of the antimonial analogues of the cacodyl series on which we have been engaged during the last three years.

Although aromatic antintonials are known containing the metal combined with one or two aryl groups, so far the only well-authenticated aliphatic antimonials belong exclusively to the tertiary stibine series in which antimony is associated with three alkyl radicals as in trimethylstibine, $\left(\mathrm{CH}_{3}\right)_{3} \mathrm{Sb}$

The following thermal decomposition,

$$
\left(\mathrm{CH}_{3}\right)_{3} \mathrm{SbX}_{2}=\left(\mathrm{CH}_{3}\right)_{2} \mathrm{SbX}+\mathrm{CH}_{3} . \mathrm{X} \text {, }
$$

has been generalised for the dihalides of trimethylstibine and leads to dimethylstibine chloride, bromide and iodide corresponding with cacodyl chloride, bromide and iodide in the arsenical series.

Dimethylstibine oxide has also been obtained, and the antimonial series has been completed in this laboratory by Mr. V. E. Yarsley's collaboration in the preparation of dimethylstibine cyanide, the analogue of Bunsen's cacodyl cyanide.

Antimony cacodyl itself has not been isolated in a state of purity, although its existence among the reduction products of dimethylstibine bromide has been demonstrated.

By carrying demethylation a stage further,

$$
\left(\mathrm{CH}_{3}\right)_{2} \mathrm{SbX}_{3}=\mathrm{CH}_{3} \cdot \mathrm{SbX}_{2}+\mathrm{CH}_{3} \cdot \mathrm{X} \text {, }
$$

we have obtained another new series of alkyl antimonials in which the metal is associated with only one methyl radical.

The following historical coincidence may also be of interest. Cacodyl and cacodyl oxide were originally prepared by L.C. Cadet de Gassicourt in I760 when engaged on service work for the French army of that day, whereas the investigations referred to in this note have arisen out of war work for the British Military Authorities. G. T. MorGan.

University of Birmingham, Edgbaston, G. R. Davies. September I 5 .

Thunderstorms and the Sound of Lightning.

I wAS interested in reading the recent correspondence in NATURE about the sound of lightning, for I also have once heard it. It was in East Griqualand one evening when, in the midst of a storm, I saw a blinding flash, followed almost instantaneously by an explosion like a shell. But between the flash and the crash there was a distinct small pistol-shot-like sound, immediately after the flash.

The Transvaal is a noted place for thunderstorms. On Christmas Day I923 I witnessed what I should imagine must almost be a world record in the way of storms. It occurred in the late afternoon and evening over the Pretoria district. From my balcony I had a fine view of it about twenty miles away on the horizon. There were really two storms, one about 6 and the other between 7 and 8.30. I saw the latter. The flashes for about twenty or thirty minutes during the time I looked on must have been at the average rate of well over one per second. Mr. Stewart, the Government meteorologist at Pretoria, kindly gave me some statistics of the storm. He said that in three minutes there were the astonishing number of 360 flashes, an average of two per second. I should imagine that for something like an hour perhaps there were an average of roo flashes per minute. It was a wonderful sight: the sky in the north towards Pretoria was simply one blaze of light. The damage done by the hail was tremendous, and one woman died from shock. It would be interesting to hear if any of the widely spread readers of NATURE in other parts of the world have ever seen a worse thunderstorm.

\section{T. B. BtathWAYT.}

Box 7532, Johannesburg, August I9.

$$
\text { No. } 29 \text { I } 8 \text {, vOL. II } 67
$$

